\title{
Induction of transcription factor AP-1 by adenovirus E1A protein and CAMP
}

\author{
Ulrich Müller, ${ }^{1}$ Michael P. Roberts, ${ }^{1}$ Daniel A. Engel, ${ }^{1}$ Walter Doerfler, ${ }^{2}$ and Thomas Shenk ${ }^{1,3}$ \\ ${ }^{1}$ Howard Hughes Medical Institute, Department of Biology, Princeton University, Princeton, New Jersey 08544 USA; ${ }^{2}$ Institut \\ für Genetik, Universität zu Köln, D-5000 Köln 41, FRG
}

\begin{abstract}
Treatment of adenovirus-infected mouse 549 cells with cAMP analogs leads to the transcriptional induction of early viral genes. E1A proteins and CAMP work in synergy to activate several of these genes. We now demonstrate that the transcription factor AP-1 is modestly induced by cAMP in S49 cells and induced to significantly higher levels by cAMP in the presence of E1A proteins. Cytoplasmic levels of $c$-fos and junB mRNAs are rapidly increased by cAMP, and the induction is substantially stronger in the presence of E1A protein. The AP-1 activity binds efficiently to both AP-1 and activating transcription factor (ATF)/cAMP response element binding protein (CREB)-binding sites present in E1A-inducible promoters and presumably plays a role in the transcriptional activation of adenovirus genes by E1A proteins and cAMP.
\end{abstract}

[Key Words: AP-1; cAMP; adenovirus E1A protein; transcriptional control]

Received August 16, 1989; revised version accepted September 28, 1989.

The adenovirus E1A transcription unit encodes a variety of nuclear localized phosphoproteins (Yee et al. 1983; Spindler et al. 1984; Harlow et al. 1985) that are involved in the transcriptional regulation of a selected set of viral and cellular genes. After infection of the host cell, the ElA $12 S$ and $13 S$ mRNAs are the first detectable viral transcripts. The products encoded by the $13 \mathrm{~S}$ mRNA activate transcription of the early viral genes and a variety of cellular genes (for review, see Berk 1986). The products encoded by the $12 \mathrm{~S}$ mRNA have been shown to repress transcription of both viral and cellular genes and appear to act through enhancer elements (Borelli et al. 1984; Velcich and Ziff 1985; Hen et al. 1985; Lillie et al. 1986, 1987; Schneider et al. 1987; Stein and Ziff 1987). Transcription by RNA polymerase II, as well as RNA polymerase III, is regulated by E1A (Berk 1986).

There is still little information available on the mechanism(s) by which ElA exerts its effects on transcription. Because E1A does not bind to DNA in a sequencespecific manner (Ferguson et al. 1985; Chatterjee et al. 1988), it is likely that E1A activates its target promoters by interacting with or modifying cellular transcription factors that bind to these promoters (for review, see Berk 1986; Jones et al. 1988). The possibility that E1A can act directly at the promoter as part of a transcription complex with cellular factors has been illustrated using Gal4-E1A fusion proteins (Lillie and Green 1989). Numerous binding sites for cellular proteins have been identified within the transcriptional control regions of E1A-regulated genes; some of these proteins may mediate an indirect mechanism of ElA-trans-activation (for review, see Berk 1986; Jones et al. 1988). One factor (or

\footnotetext{
${ }^{3}$ Corresponding author.
}

family of related factors), activating transcription factor (ATF), binds upstream of the cap sites of the viral E1A, E2, E3, and E4 genes (Lee and Green 1987; Lee et al. 1987; Hardy and Shenk 1988). The binding sites are located within promoter regions that are important elements for the efficient expression of the E1A-inducible viral genes both in vivo and in vitro (SivaRaman et al. 1986; Hanaka et al. 1987; Hurst and Jones 1987; Lee and Green 1987; Lee et al. 1987; Lin and Green 1988; Zajchowski et al. 1988; Leza and Hearing 1989|.

The consensus ATF binding site is closely related to the consensus sequence of the so-called cAMP responsive element $\left(\mathrm{CRE}\right.$; $5^{\prime}$-TGACGTCA-3'), found in cAMPinducible cellular genes. CRE-containing DNA fragments can confer CAMP inducibility to heterologous promoters (for review, see Roesler et al. 1988). The cAMP responsive element binding protein (CREB; Montminy and Bilezsikjian 1987) that appears to mediate cAMP-induced transcription also binds in vitro to ATF sites within the adenovirus genome /Hardy and Shenk 1988; Leza and Hearing 1988; Lin and Green 1988). On the basis of the sequence specificity for DNA binding and the similarity of the molecular weight between the activating transcription factor $(\mathrm{ATF})$ and CREB, it was suggested that ATF and CREB are the same protein (Hardy and Shenk 1988; Leza and Hearing 1988; Lin and Green 1988). This raises the possibility that cAMP- and ElA-mediated trans-activation may act through a common transcription factor. In fact, cAMP can induce the transcription of the adenovirus E2, E3, and E4 genes in transient transfection experiments (Sassone-Corsi 1988; Leza and Hearing 1989). In adenovirusinfected mouse 549 cells, cAMP activates the transcription of the E1A, E1B, E2, E3, and E4 genes (Engel et al. 
1988; D.A. Engel and T. Shenk, unpubl.). Furthermore, E1A and cAMP activate some of these genes synergistically, indicating that the CAMP-mediated and E1A-mediated responses are somehow linked or interactive (Engel et al. 1988). To date, no direct effect of E1A on ATF has been reported; the DNA binding activity of ATF is not increased during infection of HeLa cells with adenovirus (Lee and Green 1987; SivaRaman and Thimmappaya 1987).

The consensus binding site for the cellular transcription factor AP-1 [5'-TGA/C/G)TCA-3'] differs by only one nucleotide from the consensus DNA-binding sequence for ATF/CREB (5'-TGACGTCA-3'; Angel et al. 1987; Lee et al. 1987). It has been shown that AP-1 can bind in vitro with reduced affinity to ATF/CREB binding sites (Angel et al. 1988; Hai et al. 1988; Nakabeppu et al. 1988). In fact, AP-1 has been identified in DNA affinity chromatography purified preparations of ATF (Hai et al. 1988). Purification of AP-1 by sequence-specific DNA affinity chromatography (Angel et al. 1987; Lee et al. 1987) and the cloning of AP-1-related genes has revealed that AP-1 is composed of multiple proteins belonging to both the jun and fos gene families. Jun and Fos proteins interact as homo- and heterodimers with the AP-1-binding site /for review, see Curran and Franza 19881.

Because CAMP and E1A can synergize to activate the transcription of E1A-inducible genes in mouse S49 cells (Engel et al. 1988), we endeavored to identify transcription factors that mediate this effect. Employing DNA binding assays, we observed that the transcription factor AP-1 is activated to a modest extent by cAMP and to significantly higher levels by cAMP in adenovirus-infected cells. The AP-1 activity bound efficiently to both AP-1 and ATF/CREB-binding sites present within E1Ainducible viral transcriptional control regions. The maximal induction of AP-1 DNA-binding activity in infected cells required E1A protein, CAMP, functional protein $\mathrm{ki}$ nase $A$, and active transcription. The cytoplasmic levels of both c-fos and junB mRNAs were very rapidly increased by cAMP treatment and increased to substantially higher levels by cAMP in the presence of E1A proteins. We propose that the AP-1 activity induced in infected cells plays a major role in the cAMP- and ElA-dependent transcriptional activation of adenovirus genes.

\section{Results}

Induction of AP-1 activity upon $B t_{2} c A M P$ treatment of adenovirus-infected 549 cells

We demonstrated previously that cAMP and E1A proteins act in synergy to induce transcription of E1A-inducible adenovirus genes (Engel et al. 1988). This observation was pursued by searching for transcription factors present in S49 cells that were altered upon infection and cAMP treatment.

Extracts were prepared from uninfected, uninfected $\mathrm{Bt}_{2} \mathrm{cAMP}$-treated, infected, and infected $\mathrm{Bt}_{2} \mathrm{cAMP}$ - treated S49 cells. No significant alteration in the total amount of ATF/CREB, the chromatographic behavior of ATF/CREB, the migration of ATF/CREB-DNA complexes, or the half-life of the complexes was detected in DNA band-shift assays (data not shown). Even though there is currently no direct proof that ATF and CREB are the same protein, we refer to DNA binding activities interacting with CREB and ATF-binding sites as ATF/ CREB. Although we cannot rule out all possible changes in ATF/CREB activity, none were detected by the assays used.

In contrast, the combination of infection and elevated intracellular levels of cAMP dramatically increased AP-1-binding activity (Fig. 1). Uninfected and adenovirus-infected $\mathrm{S} 49$ cells were treated with $\mathrm{Bt}_{2} \mathrm{CAMP}$ for various lengths of time. Infected cells were harvested 24 $\mathrm{hr}$ after infection, before the onset of DNA replication, which occurred at 30-36 hr (Engel et al. 1988). Nuclear extracts were prepared, and AP-1 activity was evaluated by band-shift assay (Fried and Crothers 1981) using a ${ }^{32} \mathrm{P}$ labeled, double-stranded 35-bp oligonucleotide containing the AP-1 binding site from the collagenase gene promoter (Angel et al. 1987).

Three bands representing AP-1-DNA interactions were evident and termed complexes I, II, and III (Fig. 1). Uninfected cells (Fig. 1A) contained an activity that produced complex I. The activity was enhanced modestly by treatment with $\mathrm{Bt}_{2} \mathrm{cAMP}$. An activity responsible for complex II was induced by treatment with $\mathrm{Bt}_{2} \mathrm{cAMP}$. Complex II was first apparent at $30 \mathrm{~min}$ after $\mathrm{Bt}_{2} \mathrm{cAMP}$ treatment, although in very low amounts. Maximal activity was evident $3 \mathrm{hr}$ after treatment, and it decreased thereafter. Complex III was detected in low amounts after treatment with $\mathrm{Bt}_{2} \mathrm{cAMP}$ and was occasionally observed in untreated cells. Adenovirus-infected cells (Fig. 1B) contained low amounts of activities comigrating with complexes I, II, and III, which could only be detected in exposures longer than those in Figure 1B.

When infected cells were treated with $\mathrm{Bt}_{2} \mathrm{cAMP}$, a marked induction of complex II was observed. As for uninfected cells, the activity giving rise to complex II was induced detectably within $30 \mathrm{~min}$ of $\mathrm{Bt}_{2} \mathrm{cAMP}$ treatment. In contrast to uninfected cells, the amount of activity was greater $(\sim 10$ fold at $3 \mathrm{hr})$, and the enhanced levels were evident for a longer period of time.

All three complexes were determined to result from sequence-specific protein binding because formation of the labeled complex was decreased by addition to the binding mixture of excess, unlabeled DNA homologous to the probe (Figure 1C). Furthermore, complexes I, II, and III were formed at substantially reduced efficiency on a DNA containing a point mutation $\left(5^{\prime}\right.$-TGACTCA$3^{\prime}$ to $5^{\prime}$-TGACTCC-3') within the AP-1-binding site, and the mutated DNA fragment competed poorly with the wild-type sequence for formation of the three complexes (Fig. 1D). Angel et al. (1987) reported that this mutation reduces AP-1 binding and TPA responsiveness conferred by the AP-1-binding site under study.

We conclude that cAMP can induce an activity in uninfected S49 cells that binds to an AP-1 recognition site. 

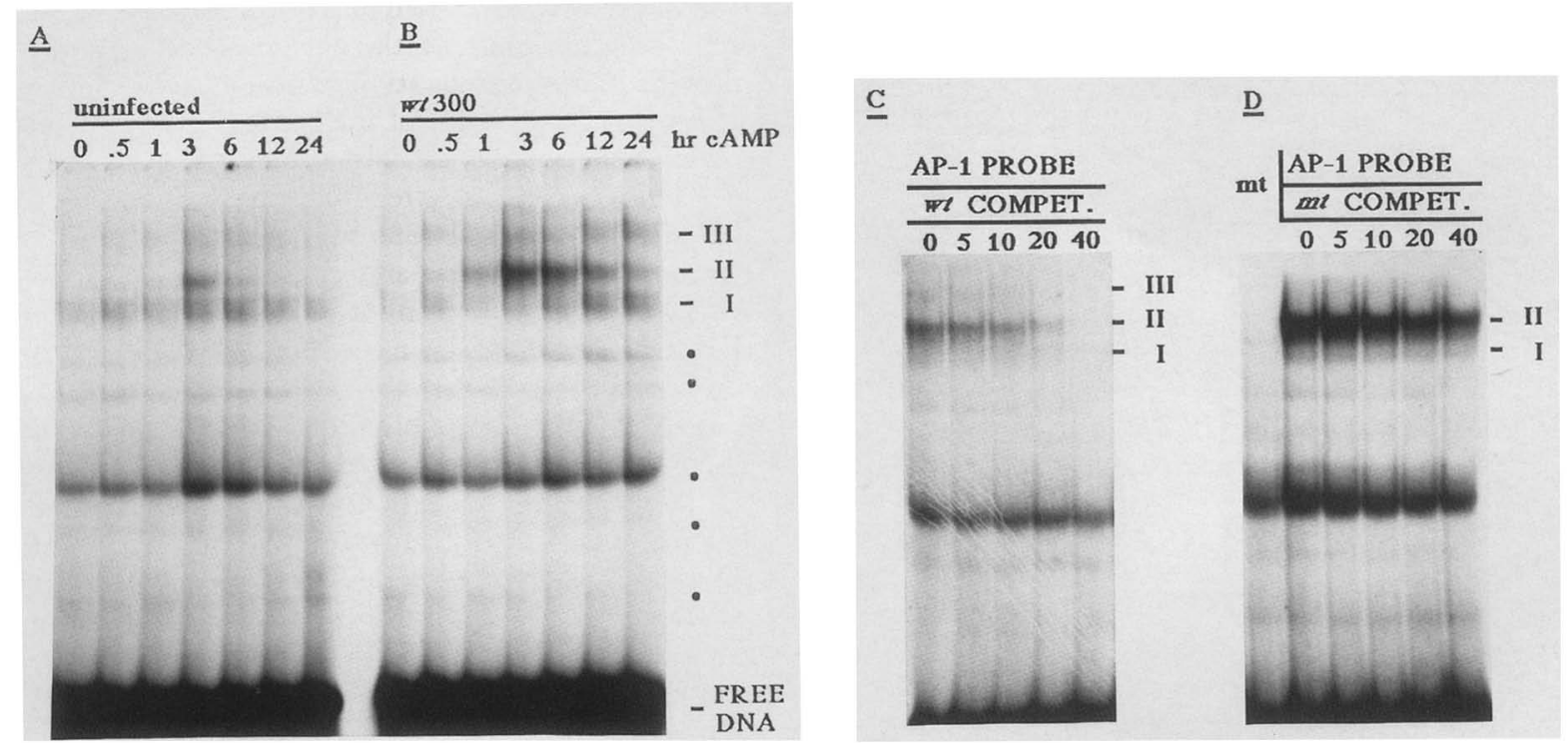

Figure 1. DNA band-shift analysis of $\mathrm{Bt}_{2} \mathrm{cAMP}$-induced activities that bind to an AP-1 recognition site. $(A$ and $B)$ Nuclear extracts from $\mathrm{S} 49$ cells that had been treated for the indicated time with $\mathrm{Bt}_{2} \mathrm{cAMP}$ were analyzed in a DNA band-shift assay using a synthetic double-stranded oligonucleotide containing an AP-1-binding site as ${ }^{32} \mathrm{P}$-labeled DNA substrate. Either extracts from uninfected $(A)$ or adenovirus $(w t 300)$-infected $(B)$ cells were analyzed. Infections were performed with $20 \mathrm{pfu} / \mathrm{cell}$, and cells were harvested $24 \mathrm{hr}$ postinfection. $\mathrm{Bt}_{2} \mathrm{cAMP}$ treatment was for the indicated time period before harvesting. DNA-protein complexes were resolved on a $4 \%$ polyacrylamide gel, the gel was dried, and DNA-protein complexes (I, II, III) were visualized by autoradiography. Additional bands were observed (dots at right) that did not result from sequence-specific DNA-protein interactions (cf. $C$ and $D)$. $(C$ and $D)$ DNA band-shift competition experiments were carried out with the indicated molar excess of unlabeled competitor DNA. The extracts used were from infected S49 cells treated for $3 \mathrm{hr}$ with $\mathrm{Bt}_{2} \mathrm{cAMP}$. The ${ }^{32} \mathrm{P}$-labeled DNA substrate was the same as that in $A$ and $B$ except for lane 1 in $D$, where an oligonucleotide with a point mutation in the AP-1-binding site was used. $(C)$ The competitor DNA had the same sequence as the ${ }^{32}$ P-labeled DNA. $|D|$ The competitor DNA carried a point mutation in the AP-1-binding site.

A substantially greater amount of a similar activity is induced by cAMP in infected 549 cells.

\section{Maximal AP-1 induction upon $B t_{2} c A M P$ treatment of infected $S 49$ cells requires E1A products}

Viral mutants were screened for their ability to induce AP-1 activity in combination with cAMP to identify the viral gene(s) involved in the induction (Fig. 2). The first mutant tested was d1312, which fails to produce E1A proteins (Jones and Shenk 1979). Infected cells were treated for various lengths of time with $\mathrm{Bt}_{2} \mathrm{CAMP}$, and cellular extracts were prepared and assayed for AP-1 activity by band-shift analysis. Although $\mathrm{Bt}_{2} \mathrm{CAMP}$ treatment of wild-type (wt300) virus-infected cells led to a marked induction of AP-1 activity, treatment of dl312infected cells did not. In fact, the response of dl312-infected cells to cAMP was indistinguishable from the response of uninfected cells (Fig. 1A). In the experiments displayed in Figure 2, cells were infected at a multiplicity of $20 \mathrm{pfu} / \mathrm{cell}$, and the E1A-dependent early viral genes were expressed by $24 \mathrm{hr}$ after infection in both wild-type and mutant d1312-infected cells (data not shown). Expression of the early adenovirus genes in the absence of E1A after an extended lag has been reported previously (Nevins 1981). The E1A gene requirement for early gene expression can also be overcome by infection with mutant viruses at a high input multiplicity (Shenk et al. 1980). The experiments were repeated with $d 1312$ at a multiplicity of infection (m.o.i.) 10-fold higher, but again, AP-1 activity was not induced to a greater extent than in uninfected cells (data not shown). The inability of $d l 312$ to provide the viral function needed to produce the cooperative response to cAMP indicated that E1A gene products were essential for the response. To confirm this conclusion, mutant viruses lacking E1B (dl313 and dl339), E2A (d1802), E3 (d1327), and E4 (d1366) functions were also tested for their ability to induce AP-1 activity in response to cAMP. A strong induction was observed in each case (data not shown).

These results indicate that E1A proteins, but not E1B, E2A, E3, or E4 proteins, are required for the increased induction of an AP-1 activity by cAMP in infected S49 cells.

\section{$A P-1$ induction by $B t_{2} c A M P$ requires protein kinase $A$ and transcription}

AP-1 has been shown to be activated in response to TPA, probably via protein kinase C (Angel et al. 1987; Lee et al. 1987), and our present data indicate that AP-1 can be induced by cAMP. This raised the possibility that the cAMP-dependent protein kinase A may also control AP-1 activity. Accordingly, we tested whether protein 


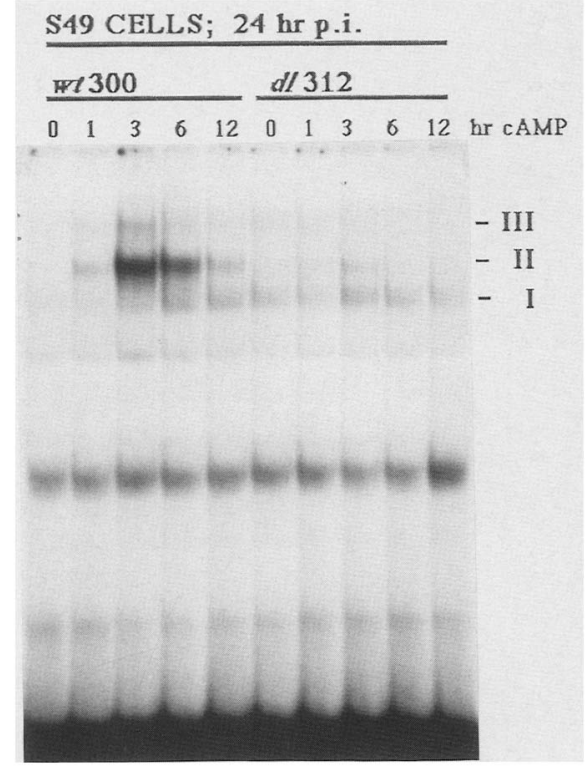

Figure 2. E1A dependence of the CAMP-induced AP-1 binding activities. S49 cells were infected at a m.o.i. of $20 \mathrm{pfu} /$ cell with wild-type adenovirus (wt300) or with the E1A deletion virus d1312. All cells were harvested at $24 \mathrm{hr}$ postinfection. $\mathrm{Bt}_{2} \mathrm{cAMP}$ treatment was for the indicated time period before harvesting. Nuclear extracts were prepared and analyzed in a DNA bandshift assay. The same ${ }^{32} \mathrm{P}$-labeled DNA substrate as that in Fig. 1 was used. Specific DNA-protein complexes (I, II, III) are indicated.

kinase activity was required for the induction of AP-1 by cAMP in adenovirus-infected cells using the protein $\mathrm{ki}$ nase blocker $\mathrm{H} 8$. The antagonist was added to infected $\mathrm{S} 49$ cells $10 \mathrm{~min}$ before $\mathrm{Bt}_{2} \mathrm{CAMP}$. Extracts were then prepared after various periods of $\mathrm{Bt}_{2} \mathrm{cAMP}$ treatment and assayed for AP-1 activity by band-shift analysis. H8 completely blocked the induction of AP-1 activity (Fig. 3A). Although $\mathrm{H} 8$ antagonizes protein kinase A more effectively than it does protein kinase $\mathrm{C}$ (Hidaka et al. 1984), H8 does not provide an absolute discrimination. To determine more directly if protein kinase A activity was required for AP-1 induction, B1R cells were employed. These cells are a subline of $\$ 49$ cells deficient in protein kinase A activity (Bourne et al. 1975; Coffino et al. 1975). cAMP failed to induce AP-1 activity in infected B1R cells (Fig. 3A), indicating that protein kinase A plays an essential role in the induction process.

Treatment of infected S49 cells with actinomycin D also blocked the ability of cAMP to induce AP-1 activity (Fig. 3A), indicating that transcription is required for the induction to occur.

Several control experiments were performed to rule out nonspecific or indirect effects of $\mathrm{H} 8$ and actinomycin D. First, an unrelated DNA-binding protein, major late transcription factor (MLTF), was tested, and its activity was not altered by the inhibitors (Fig. 3B). Second, the adenovirus E1A protein was monitored by protein blot analysis, and its level did not change during the course of the experiment (data not shown).
In summary, maximal induction of AP-1 activity in adenovirus-infected $\mathrm{S} 49$ cells by cAMP requires E1A proteins, protein kinase $A$, and active transcription.

\section{Stimulation of jun $B$ and $c$-fos mRNA levels by $B t_{2} c A M P$ treatment of infected $S 49$ cells}

Because fos and jun family members are components of AP-1 activity (for review, see Curran and Franza 1988), the requirement for transcription to induce AP-1 (Fig. $3 \mathrm{~A})$ raised the possibility that the c-fos gene and one or more iun genes were activated by $\mathrm{Bt}_{2} \mathrm{cAMP}$ treatment. Therefore, we performed RNase protection experiments to determine the effect of cAMP on the levels of c-fos and jun-specific mRNAs in uninfected versus infected S49 cells (Fig. 4). In uninfected cells, $\mathrm{Bt}_{2} \mathrm{CAMP}$ treatment increased the levels of $\mathrm{c}$-fos and junB mRNAs. Induction kinetics were similar for the two mRNAs, with induction evident at the first time point tested, $30 \mathrm{~min}$ after addition of $\mathrm{Bt}_{2} \mathrm{CAMP}$. A much more dramatic induction of the two mRNAs was observed upon $\mathrm{Bt}_{2} \mathrm{cAMP}$ treatment of infected S49 cells. This induction was E1A dependent, because it was not observed in cells infected at high multiplicity with an ElA ${ }^{-}$virus (data not shown). The c-jun and junD mRNAs were also monitored, but their levels did not increase in response to E1A protein plus cAMP (data not shown).

We conclude that accumulation of c-fos and junB mRNAs, but not c-jun and junD mRNAs, is stimulated by treatment of infected cells with $\mathrm{Bt}_{2} \mathrm{cAMP}$. Although we have not directly demonstrated that the enhanced mRNA accumulation results from an increased rate of transcription, this seems very likely given the requirement for active transcription in the induction process.

\section{AP-1 activity induced by cAMP in uninfected and adenovirus-infected $S 49$ cells contains polypeptides immunologically related to $c$-fos and jun}

The activity under study appears to be AP-1 because it bound to an AP-1 recognition site. AP-1 has been shown to be comprised of protein complexes formed between various combinations of c-fos, fos-related antigens, and jun polypeptides (for review, see Curran and Franza 1988). To further verify the identity of the activity induced by $\mathrm{Bt}_{2} \mathrm{cAMP}$ treatment of adenovirus-infected $\mathrm{S} 49$ cells, its constituents were probed with different antibodies (described in Materials and methods) specific for c-fos or the jun family of polypeptides. Nuclear extracts were mixed with antibodies, incubated for $15 \mathrm{~min}$ at $0^{\circ} \mathrm{C}$, and ${ }^{32} \mathrm{P}$-labeled DNA containing an AP-1-binding site was added. After incubation for an additional $30 \mathrm{~min}$ at room temperature, DNA-protein complexes were resolved on nondenaturing polyacrylamide gels (Fig. 5). When polyclonal antibodies to the c-fos protein were mixed with extracts of uninfected or infected cells treated with $\mathrm{Bt}_{2} \mathrm{cAMP}$, the formation of complex II, but not of complex I, was abolished (Fig. 5A). A new complex with a slower mobility was observed. Three lines of evidence indicate that the slower migrating complex re- 

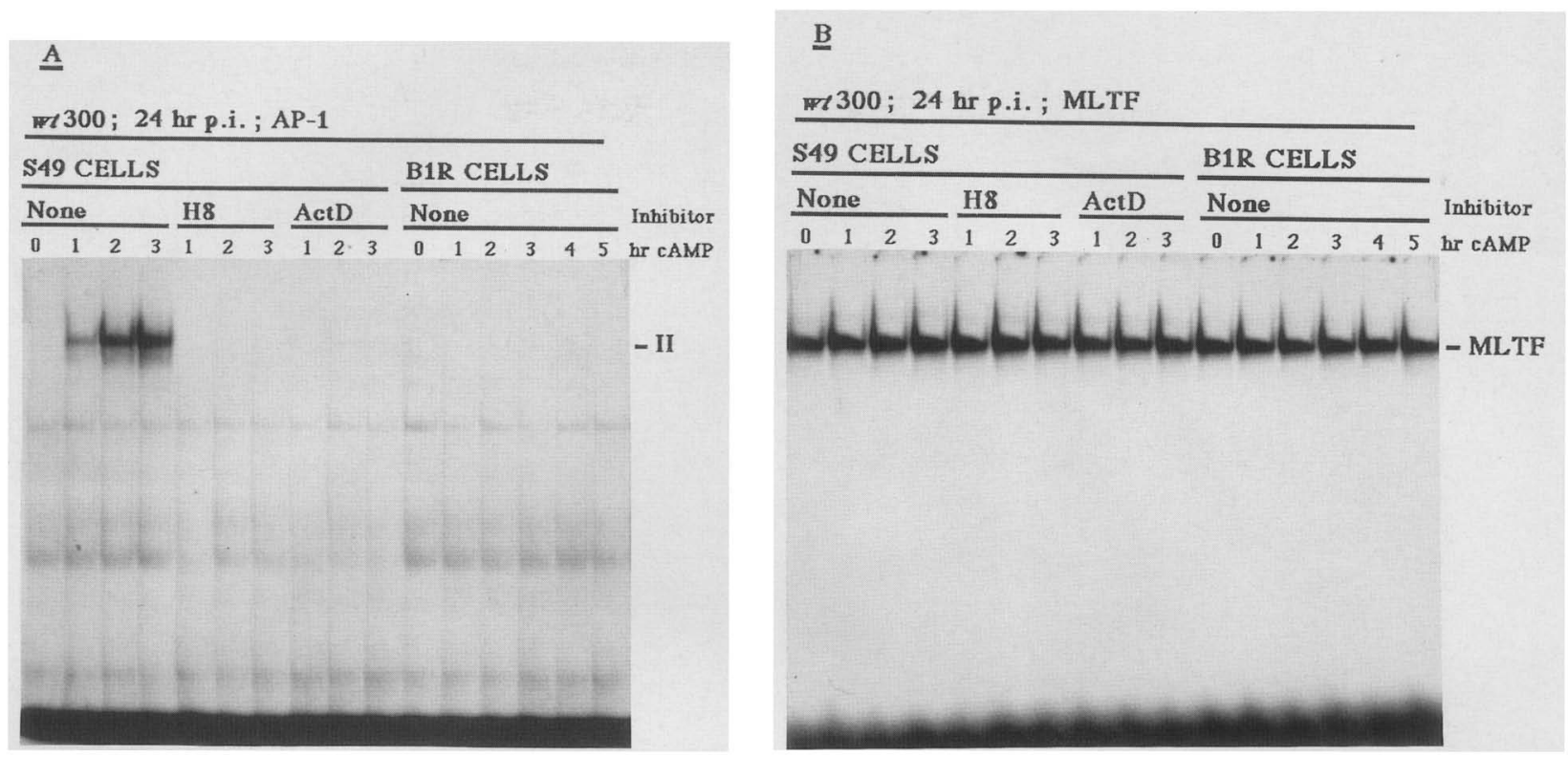

Figure 3. Requirement for protein kinase A and transcription. Nuclear extracts were prepared at 24 hr postinfection of S49 or BlR cells at a m.o.i. of $20 \mathrm{pfu} / \mathrm{cell}$ with adenovirus (wt300). Cells were treated for the final $0,1,2$, and 3 hr before harvesting with $\mathrm{Bt}_{2} \mathrm{cAMP}$. Where indicated, protein kinase blocker $\mathrm{H} 8$ or actinomycin $\mathrm{D}$ was added 10 min prior to addition of $\mathrm{Bt}_{2} \mathrm{CAMP}$. Nuclear extracts were analyzed in a DNA band-shift assay. The ${ }^{32}$ P-labeled DNA substrate was the same DNA as that in Fig. 1A or a synthetic oligonucleotide containing a recognition site for $\operatorname{MLTF}(B$; see Table 1$)$.

sulted from a specific interaction between the antibody and a protein immunologically related to the c-fos polypeptide within the cAMP-induced complex. First, complex II, but not complex I, was displaced, ruling out the possibility that all DNA-binding activities were nonspecifically disrupted. Second, a DNA-protein complex containing MLTF, but not c-fos, was not affected by the antibody. Third, a second c-fos-specific antibody, raised against a synthetic polypeptide, also abolished formation of complex II. Its effects were blocked by preincubation with the peptide used for immunization.

Polyclonal antibodies to the jun family of polypeptides prevented formation of both complex I and complex II (Fig. 5B). In control experiments, a complex containing MLTF was not affected by the jun antibody, and preimmune serum did not affect complex I and II or a complex containing MLTF.

We conclude that the activity induced by $\mathrm{Bt}_{2} \mathrm{CAMP}$ treatment of either uninfected or infected S49 cells, which gives rise to complex II, is comprised of proteins immunologically related to c-fos and the iun family. Complex I contains polypeptides immunologically related to jun but not to fos.

\section{$A P-1$ activity binds efficiently to $A T F / C R E B$ recognition sites}

ATF/CREB recognition sequences have been implicated in E1A-mediated trans-activation (Lee and Green 1987; Lee et al. 1987; Hardy and Shenk 1988; Leza and Hearing 1988). Transient assays have indicated that cAMP and E1A proteins can induce transcription of adenovirus early genes through ATF/CREB recognition sites (Lee and Green 1987; Leza and Hearing 1989|. However, we found no significant change in the cognate ATF/CREB activity, whereas AP-1 activity was substantially increased when infected cells were treated with $\mathrm{Bt}_{2} \mathrm{CAMP}$ (Fig. 1). This led us to test the possibility that AP-1 can bind to ATF/CREB-binding sites. Oligonucleotides containing various ATF/CREB-binding sites were used to compete for AP-1 binding with the ${ }^{32}$ P-labeled AP-1 site from the collagenase gene promoter. The source of AP-1

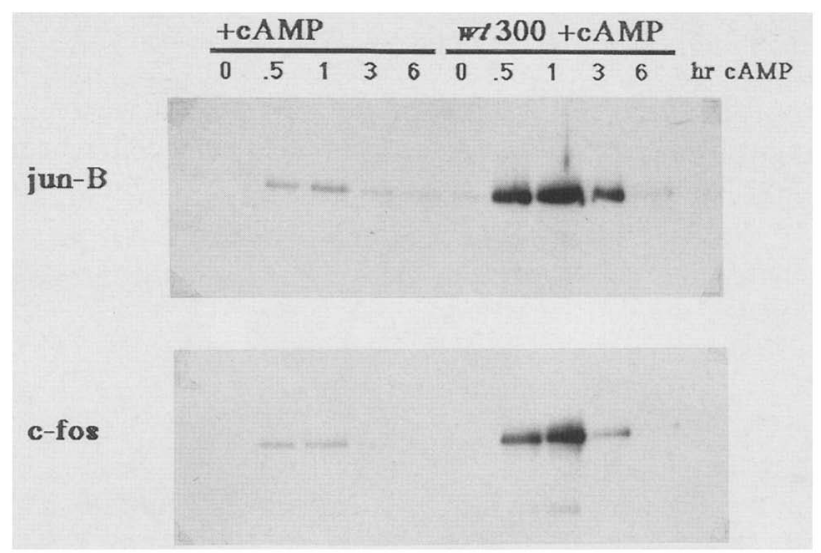

Figure 4. Effect of $\mathrm{Bt}_{2} \mathrm{cAMP}$ on cytoplasmic levels of $\mathrm{c}$-fos and junB mRNA in uninfected and infected S49 Cells. Cytoplasmic RNA from uninfected or infected $\mathrm{S} 49$ cells, which had been treated for the indicated time with $\mathrm{Bt}_{2} \mathrm{CAMP}$, was analyzed by RNase protection for cytoplasmic levels of $\mathrm{c}$-fos and junB mRNA. 

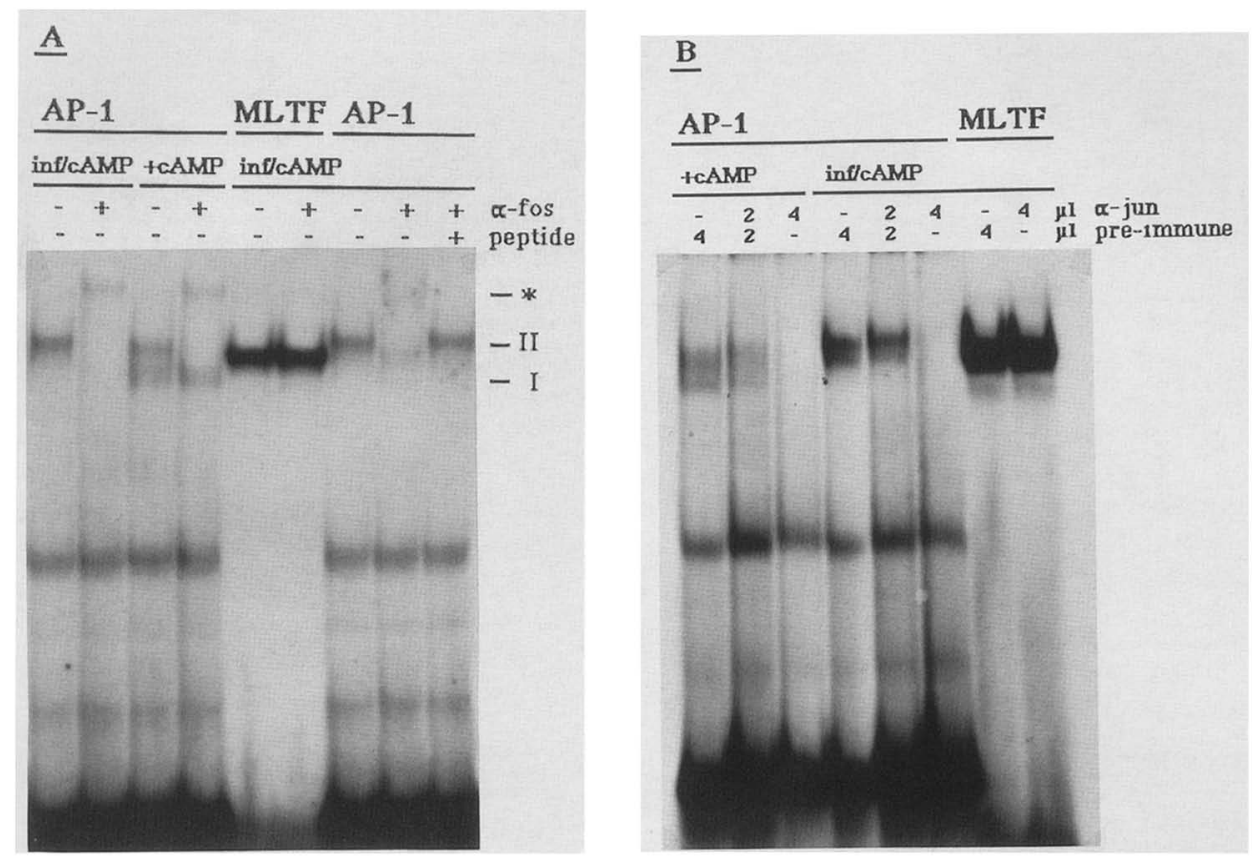

Figure 5. Immunological analysis of the AP-l-binding activities. A DNA band-shift analysis was performed with the indicated extracts and ${ }^{32} \mathrm{P}$-labeled probe DNA. Where indicated, affinity-purified polyclonal anti-c-fos $(A)$ or anti-jun serum or affinity-purified preimmune serum $(B)$ was mixed into the binding reaction. In lane 9 the antiserum was added to the binding reaction after it was blocked for 30 min with the c-fos peptide, which was used as immunogen. Specific DNA-protein complexes are indicated (*, I, II).

was an extract of infected $\mathrm{S} 49$ cells that was treated for $4 \mathrm{hr}$ with $\mathrm{Bt}_{2} \mathrm{CAMP}$, and binding was monitored by bandshift assay (Fig. 6). All of the ATF/CREB recognition sites tested (sequences in Table 1) were able to compete for binding of AP-1 to the collagenase AP-1 site. The ATF/CREB sites from somatostatin, fibronectin, E1A, E2, and E4 genes competed for AP-1 binding nearly as well as the AP-1 sites did. The E3 ATF/CREB site competed poorly, and a DNA fragment from the adenovirus E2 promoter that contained neither an ATF/CREB nor AP-1 consensus binding site (labeled 'unspecific' in Fig. 6) failed to compete. The autoradiographic exposures displayed in Figure 6 were selected to permit effective evaluation and direct comparison of the effects of competitor DNAs on the formation of complex II. Complexes I and III are not shown but behaved like complex II. Similar results were obtained in competition assays performed using extracts derived from uninfected cells treated with $\mathrm{Bt}_{2} \mathrm{cAMP}$ (data not shown).

To demonstrate directly the binding of AP-1 to ATF/ CREB recognition sites, a nuclear extract prepared from cAMP-treated, infected cells was subjected to chromatography on a DEAE-5PW matrix. AP-1 and ATF/CREB activities were localized in the chromatographic fractions by band-shift assays using specific probe DNAs (Fig. 7). The AP-1-specific probe DNA detected the induced activity that formed complex II primarily in fractions 45-48 (Fig. 7B). The major peak of ATF/CREB activity was localized in fractions 37-42 using an ATF/ CREB probe. However, a second activity that generated a shifted complex with a mobility similar to complex II was present in fractions $45-48$, when analyzed with the ATF/CREB probe DNA (Fig. 7A). In fact, the complexes detected on AP-1 and ATF/CREB probe DNAs labeled to the same specific activity appeared in comparable amounts and showed identical electrophoretical mobility. Both were disrupted and shifted by an antibody to c-fos, a component of AP-1 activity (Fig. 7C). The small amount of ATF/CREB activity cofractionating with AP-1 was not affected by the antibody. Thus, fractions 45-48 contain an AP-1 activity that binds to both AP-1 and ATF/CREB recognition sites.

As mentioned above, no change in the binding of nuclear proteins to ATF/CREB sites was observed upon treatment of infected cells with cAMP. The much greater quantity of ATF/CREB activities masked the AP-1 induction. It was necessary to separate the activities chromatographically (Fig. 7A) to directly demonstrate binding of the induced AP-1 to an ATF/CREB site.

We conclude that AP-1 can bind efficiently to several different ATF/CREB recognition sites. ATF/CREB, however, did not bind efficiently to an AP-1 probe DNA. In fractions 37-42 only a low amount of DNA-binding activity was detected on an AP-1 probe DNA if compared to an ATF/CREB probe DNA (cf. Fig. 7A and B). In agreement with this data, ATF/CREB complexes formed on ${ }^{32}$ P-labeled ATF/CREB probe DNA could not be competed with unlabeled AP-1 DNA (data not shown).

\section{Discussion}

We draw three main conclusions from these results, 


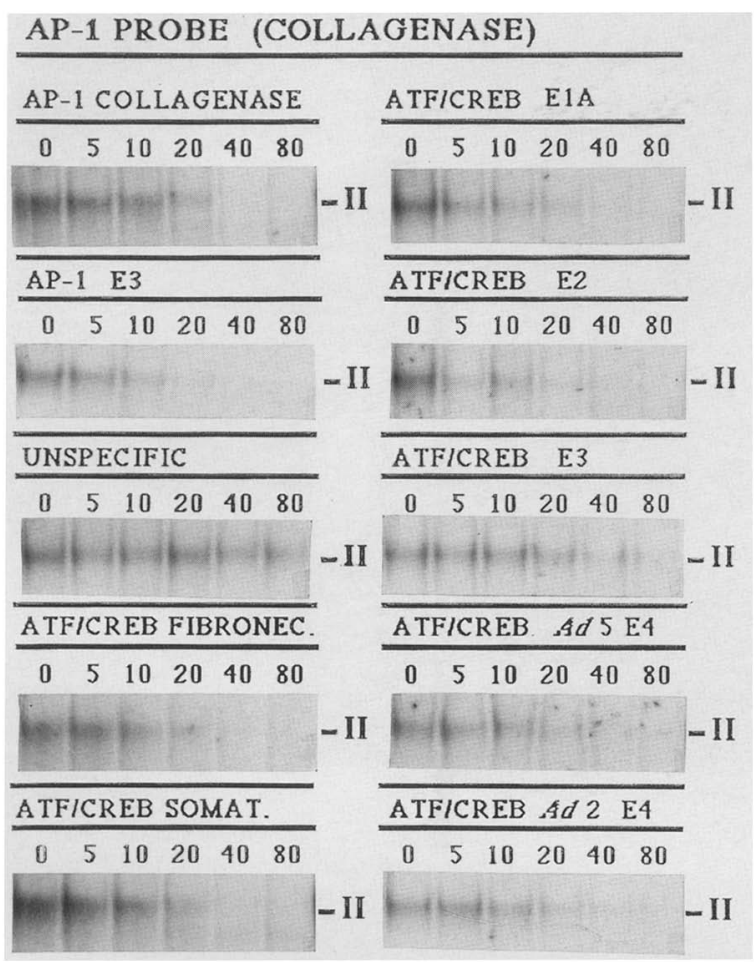

Figure 6. Competition analyses in a DNA band-shift assay . (A) Nuclear extracts from adenovirus (wt300)-infected and $\mathrm{Bt}_{2} \mathrm{CAMP}$-treated cells were incubated with the same ${ }^{32} \mathrm{P}-\mathrm{la}$ beled DNA substrate as in Fig. 1. The binding reaction contained the indicated excess of unlabeled competitor DNA over ${ }^{32}$ P-labeled DNA. The sequences of the synthetic oligonucleotides used as competitors were derived from the promoters of the indicated genes (listed in Table 1). Only the part of the gel showing complex II is displayed. The same extracts and the same preparation of ${ }^{32} \mathrm{P}$-labeled DNA were used in each experiment, and all competitions were performed in parallel. The concentrations of the different competitor DNAs were standardized against each other.
First, AP-1 is induced by cAMP in uninfected S49 cells, and the induction is substantially greater in the presence of E1A proteins (Fig. 1). The DNA-binding activity was identified as AP-1 because it binds to AP-1 recognition sites (Fig. 1 and 6) and contains polypeptides immunologically related to c-fos and jun proteins (Fig. 5). Our second conclusion is that cAMP treatment of S49 cells in the presence of ElA proteins leads to a stronger induction of cytoplasmic levels of junB and c-fos mRNA than cAMP treatment alone (Fig. 4). The fact that active transcription is required for the induction of AP-1 DNAbinding activity by cAMP (Fig. 3) suggests that the AP-1 activity under study is composed of c-fos and junB polypeptides, two known components of AP-1 (Distel et al. 1987; Franza et al. 1988; Nakabeppu et al. 1988; Rauscher et al. 1988a; Ryder et al. 1988). Third, we show that the AP-1 activity induced by cAMP in both uninfected and infected $S 49$ cells binds to ATF/CREB, as well as AP-1 recognition sites. Interaction of AP-1 with these related DNA sequences was demonstrated by binding competition experiments (Fig. 6) and direct binding of a partially purified AP-1 activity to an ATF/CREB recognition site (Fig. 7). AP-1 was separated chromatographically from ATF/CREB (Fig. 7), further arguing that the activity under study was AP-1 and not ATF/CREB.

Our results imply that the AP-1-binding activity is involved in the activation of adenovirus genes by CAMP and E1A protein in $\$ 49$ cells. The synergistic effect of cAMP and E1A protein on AP-1 correlates with activation of viral genes in S49 cells during infection and treatment with cAMP (Engel et al. 1988). The fact that E1A and cAMP increase the amount of c-fos and junB mRNAs is consistent with transcriptional activation occurring as a result of the increase in AP-1 levels. AP-1 is further implicated in the transcriptional activation of viral genes because it can bind to ATF/CREB sites that are components of the transcriptional control region of early viral genes (SivaRaman et al. 1986; Hanaka et al.

Table 1. Sequence of oligonucleotides

\begin{tabular}{|c|c|c|c|}
\hline Gene & $\begin{array}{l}\text { Binding } \\
\text { site }\end{array}$ & Sequence & $\begin{array}{l}\text { Distance } \\
\text { to } 5 \text { ' cap }\end{array}$ \\
\hline SV40 & AP-1 & TGAC $\underline{\text { TAA }}$ & \\
\hline Collagenase & AP-1 & GGATGTTATAAAGCA $\overline{\bar{T}} \overline{G A G} \overline{\underline{T}} \overline{\bar{C}} \bar{C} C T C A G G G G C G C A$ & -66 \\
\hline Ad5 E3 & AP-1 & AAGTTCAGA $\bar{T} \overline{\mathrm{T} A C}$ T的 & -92 \\
\hline Somatostatin & CREB/ATF & 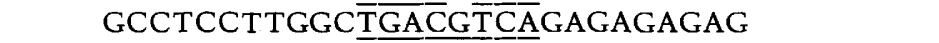 & -48 \\
\hline Fibronectin & CREB/ATF & ACAGTCCCCCGTGACGTCACCCGGGAGCCC & -173 \\
\hline$A d 2 \mathrm{E} 1 \mathrm{~A}$ & CREB/ATF & 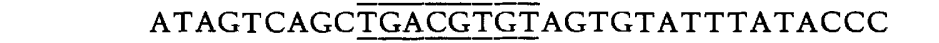 & -43 \\
\hline Ad2 $\mathrm{E} 2$ & CREB/ATF & CTGGAGATGACGTAGTTTTCGCGCTTAAATTT & -76 \\
\hline Ad2 E3 & CREB/ATF & GCGGGCGGCTTTCGT CACAGGGTGCGGTC & -61 \\
\hline Ad2 E4 & CREB/ATF & AAATGGGAAGT $\bar{T} \overline{\mathrm{G}} \overline{\mathrm{A}} \mathrm{CG} \overline{\mathrm{AT}} \mathrm{T}$ CGTGGGAAAAC & -163 \\
\hline Ad5 E4 & CREB/ATF & GGAAGT $\overline{\text { GACGT }}$ A & -163 \\
\hline \multirow[t]{2}{*}{ Ad2 E2 } & unspecific & ATTATGAGCAAGGA $\bar{A} \overline{A T C} \bar{C} \overline{C A} C G C C C T A C A T G T$ & -119 \\
\hline & MLTF & GAGGTCACGTGAGTGT & -54 \\
\hline
\end{tabular}

The sequence of one strand of each DNA used in band-shift experiments is tabulated. The underlined sequence corresponds to the indicated factor-binding site. The distance to the $5^{\prime}$ cap is measured from the $5^{\prime}$ base pair of the factor-binding site. All of the adenovirus CREB/ATF-binding sites listed have been shown to compete against bona fide CREB recognition sites for binding of the factor (Hardy and Shenk 1988). 

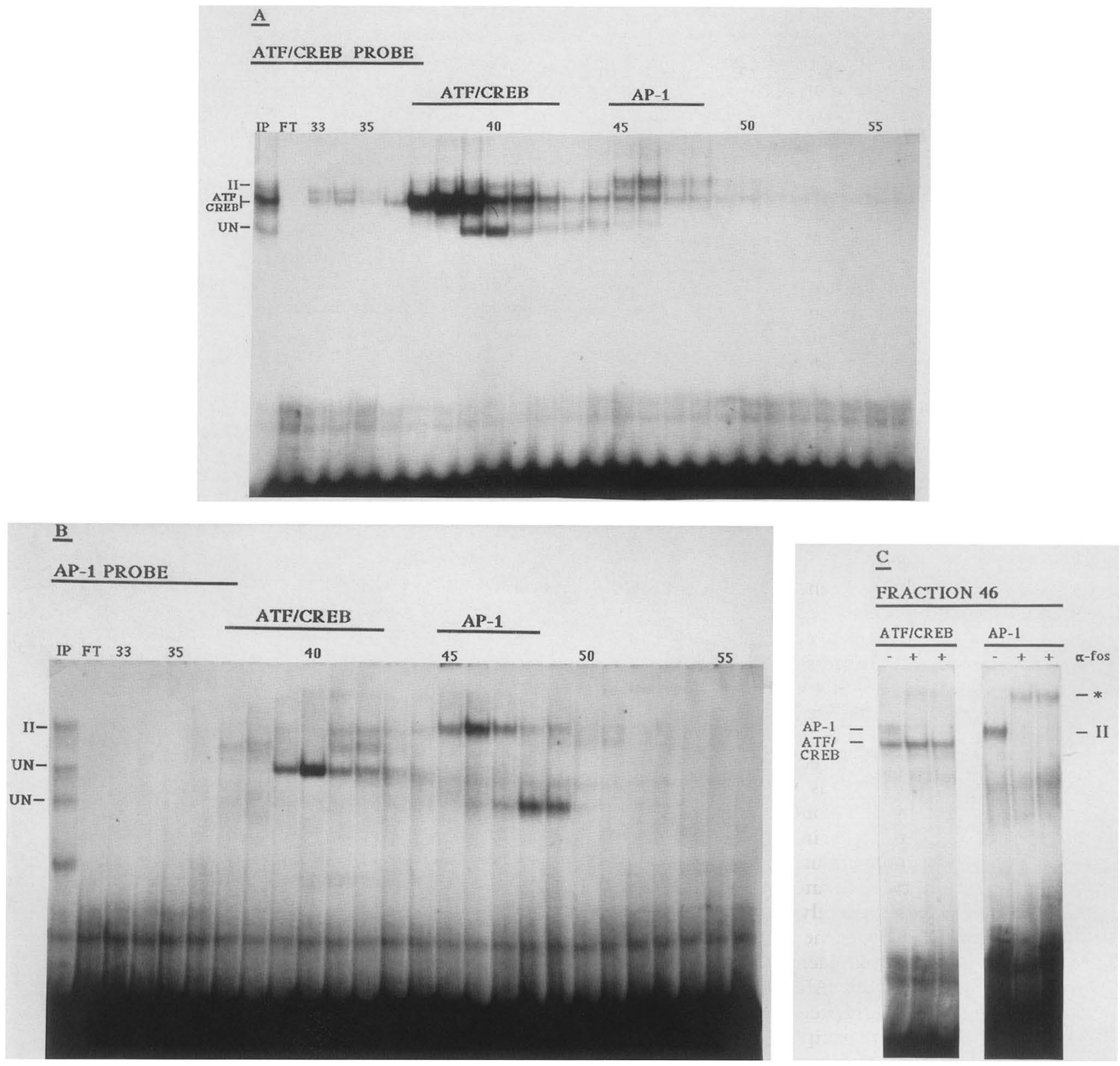

Figure 7. DNA band-shift analyses of fractionated $\mathrm{S} 49$ cell nuclear extracts. $(A$ and $B)$ Nuclear extracts from infected and $\mathrm{Bt}_{2} \mathrm{cAMP}$ treated S49 cells were fractionated using a DEAE-5PW anion exchange column, and the indicated fractions were analyzed in a DNA band-shift assay employing an ATF/CREB-binding site-containing DNA as a ${ }^{32} \mathrm{P}$-labeled DNA substrate $(A$; sequence derived from the fibronectin gene promoter; see Table 1$)$ or an AP-1-binding site-containing DNA as a ${ }^{32} \mathrm{P}-$-labeled DNA substrate $(B$; the same DNA as in Fig. 1). Specific DNA - protein complexes (II, ATF/CREB) and unspecific (un) complexes are indicated. The formation of the specific, but not the unspecific, complexes was inhibited by addition to the binding mixture of excess, unlabeled DNA homologous to the probe. $(C)$ A DNA band-shift analysis was performed with fraction 46 . The binding reaction contained the indicated ${ }^{32} \mathrm{P}-$ labeled DNA probes (the same as in $A$ and $B$ ) and, where indicated, antibodies against c-fos.

1987; Hurst and Jones 1987; Lee and Green 1987; Lee et al. 1987; Lin and Green 1988; Zajchowski et al. 1988; Leza and Hearing 1989). Furthermore, the adenovirus E3 promoter contains an AP-1-binding site (Hurst and Jones 1987), which efficiently binds AP-1 (Fig. 6).

The AP-1 activity induced by cAMP in the presence or absence of E1A interacted with a variety of AP-1 and
ATF/CREB-binding sites with similar affinities (Fig. 6; data not shown). It has been reported that AP-1 can bind to ATF/CREB sites (Angel et al. 1988; Cohen et al. 1989; Hai et al. 1988; Nakabeppu et al. 1988; Rauscher et al. 1988a), but with a markedly lower affinity than for AP-1 sites (Angel et al. 1988; Nakabeppu et al. 1988). Possibly the specific polypeptide composition of AP-1 
(e.g. which jun family member), the modification states of its constituents, or the sequence context of recognition sites affects the affinity of the binding interaction.

How do E1A and cAMP cooperate to induce a high level of AP-1 activity? As yet, we cannot be certain. Conceivably, ElA acts on or in concert with proteins that are modified by protein kinase A, because cAMP is reported to act through this kinase (for review, see Nairn et al. 1985), and it is required for induction of both transcription through cAMP treatment (Engel et al. 1988) and AP-1 activity (Fig. 3). It is even possible that E1A may act directly on the kinase itself. Viral early genes are clearly not entirely dependent on an activation mechanism that requires protein kinase A activity, because they are transcribed in protein kinase A-deficient BlR cells (Engel et al. 1988). These genes very likely can be activated by multiple pathways. One additional pathway could involve the TATA-box-binding factor TFIID. The TATA box has been shown to play a key role in trans-activation of the viral E1B (Wu et al. 1987) and major late transcription units (Leong et al. 1988) as well as the cellular $\beta$-globin (Green et al. 1983) and hsp70 genes (Simon et al. 1988).

The response of early viral genes to E1A through multiple pathways makes sense, because it is almost certainly necessary for the virus to activate gene expression in a variety of cell types expressing different activation pathways to spread successfully within an infected host animal. Some nonviral genes are not as flexible in their response to E1A. Cytoplasmic levels of junB and c-fos mRNAs were modestly induced by cAMP alone and strongly induced by cAMP plus E1A; however, we did not detect induction by E1A alone (Fig. 7).

It seems likely that the large increase in AP-1 activity in response to E1A proteins plus cAMP (Fig. 1B) is not the only effect of the two activators. Production of high levels of AP-1 activity very likely required transcription (Fig. 3) of the junB and c-fos genes (Fig. 4). However, enhanced transcription of the adenovirus $\mathrm{E} 4$ gene in response to E1A proteins plus cAMP was evident within 15 min (Engel et al. 1988). Fifteen minutes is probably too short a time for the transcription, processing, transport, and translation of one or more mRNAs, as well as for the localization of the product to the nucleus to enhance transcription of the E4 gene. Presumably, an existing activity is initially modified, and this modified activity then mediates the initial transcriptional activation of viral genes and AP-1 constituents. The dramatically increased levels of AP-1 would then contribute to the magnitude of the transcriptional response and its duration. A similar situation has been reported for the induction of the c-jun gene in HeLa cells. The c-jun promoter is activated by its own gene product upon TPA treatment (Angel et al. 1988) by a feedback mechanism possibly involving modification of preexisting AP- 1 activity.

AP-1 is activated by a variety of external stimuli. AP-1 was linked to transcriptional activation of eukaryotic promoters by TPA, through a mechanism very likely involving protein kinase C (Angel et al. 1987; Lee et al.
1987). Imagawa et al. (1987) reported that AP-1-binding sites do not confer cAMP inducibility to a heterologous promoter if analyzed in HeLa cells. However, Deutsch et al. (1988) showed that AP-1 sites can confer cAMP inducibility in HepG2 and JEG-3 cells but only if the sites are located in certain sequence contexts. Piette et al. (1988) reported an increase in AP-1 DNA binding activity in NIH-3T3 cells, but the precise nature of the DNA binding activity and functional significance was not analyzed. We now report that AP-1 can probably be induced in S49 cells by cAMP via protein kinase A. In agreement with earlier findings, we observed that cytoplasmic RNA levels of one of the constituents of AP-1, c-fos, is induced by cAMP (Greenberg et al. 1985; Kruijer et al. 1985, Bravo et al. 1987). Furthermore, we found that cytoplasmic levels of junB mRNA, coding for a second component of AP-1 (Nakabeppu et al. 1988; Ryder et al. 1988) and known to be transcriptionally activated by a variety of growth hormones (Ryder et al. 1988), can be stimulated by cAMP. The induction might be cell-type dependent, as has been shown for the induction by transforming growth factor $\beta$ (TGF- $\beta$ ), which differentially induces c-fos, c-jun, and junB mRNA levels in different cell lines (Pertovaara et al. 1989). In this respect, it is intriguing that mRNA accumulation of only one jun family member, junB, was activated by E1A proteins and cAMP in $S 49$ cells.

\section{Materials and methods}

\section{Cells and viruses}

S49 cells were obtained from the Cell Culture Facility of the University of California (San Francisco). B1R cells were a gift from Dr. Vincent Groppi (The Upjohn Company). S49 and B1R cells were grown as suspension cultures in medium supplemented with $10 \%$ heat-inactivated horse serum (GIBCO). Wild-type and mutant adenoviruses were grown and titered as described (Jones and Shenk 1979; Hearing and Shenk 1985). Mutant viruses used in this investigation were initially reported as follows: $d 1312$ and dl313 (Jones and Shenk 1979), dl802 (Rice and Klessig 1985), dl327 (Thimmappaya et al. 1982), dl339 (Logan et al. 1984), and dl366 (Halbert et al. 1985).

\section{Viral infections and preparation of cellular extracts}

Exponentially growing S49 and B1R cells were harvested at a cell density between $1 \times 10^{6}$ and $2 \times 10^{6} \mathrm{cells} / \mathrm{ml}$ and resuspended in medium at a density of $1 \times 10^{7}$ cells $/ \mathrm{ml}$. Virus was added (usually $20 \mathrm{pfu} / \mathrm{cell}$ ), and after $1 \mathrm{hr}$ of incubation at $37^{\circ} \mathrm{C}$, cells were diluted to $5 \times 10^{5}$ cells $/ \mathrm{ml}$ with medium supplemented with $10 \%$ heat-inactivated horse serum. Cells were harvested at 24 or $48 \mathrm{hr}$ postinfection. Individual culture dishes (infected and uninfected) were treated for the appropriate time with a final concentration of $1 \mathrm{mM} \mathrm{Bt}{ }_{2} \mathrm{cAMP}$ (BoehringerMannheim). Spinner cells were treated with forskolin (10 $\mu \mathrm{M}$ final concentration/ instead of $\mathrm{Bt}_{2} \mathrm{cAMP}$. When the protein kinase inhibitor $\mathrm{H} 8$ (Seikagaku) or actinomycin D was used, each was added to a final concentration of $150 \mu \mathrm{M}$ or $0.1 \mu \mathrm{g} / \mathrm{ml}$, respectively, 10 min before $\mathrm{Bt}_{2} \mathrm{CAMP}$ was added.

Preparation of nuclear extracts for high performance liquid chromatography (HPLC) followed the protocol described by 
Dignam et al. (1983), with the following modifications. $\mathrm{NaCl}$ was used instead of $\mathrm{KCl}$, and, in addition to PMSF, two other protease inhibitors were routinely included in extraction buffer C [10 $\mu \mathrm{g} / \mathrm{ml}$ leupeptin (Boehringer-Mannheim), and $10 \mu \mathrm{g} / \mathrm{ml}$ trypsin/chymotrypsin inhibitor (Sigma)].

To prepare nuclear extracts for all other experiments, cells were harvested, washed twice with ice-cold PBS, lysed by incubating for $5 \mathrm{~min}$ at $0^{\circ} \mathrm{C}$ in two times the cell volume of Triton lysis buffer $\left[150 \mathrm{~mm} \mathrm{NaCl}, 1 \mathrm{~mm} \mathrm{MgCl}_{2}, 10 \mathrm{~mm}\right.$ Tris- $\mathrm{HCl}$ (pH $7.5), 0.08 \%$ Triton X-100], and nuclei were spun down. The cytoplasmic fraction was used for the preparation of RNA. The nuclei were resuspended in one to two times the nuclear volume with extraction buffer $\mathrm{C}$ and incubated for $1 \mathrm{hr}$ on ice, nuclear debris was pelleted by centrifugation, and the supernatant (nuclear extract) aliquoted and stored at $-80^{\circ} \mathrm{C}$. The protein concentration of the extracts was determind by the Bradford method (Bradford 1976).

\section{HPLC chromatography}

All chromatographic procedures were carried out at $0-4^{\circ} \mathrm{C}$. Nuclear extracts were dialyzed against buffer A 25 mM HEPES (pH 7.9), 1 mM EDTA, $1 \mathrm{~mm}$ dithiothreitol, $0.1 \mathrm{~mm}$ PMSF, 10\% (vol/vol) glycerol] and applied (20-40 mg protein) to a DEAE-5PW column (Glass-Pak DEAE-5PW, $0.8 \times 7.5 \mathrm{~cm}, \mathrm{LKB}$ ) at a flow rate of $0.5 \mathrm{ml} / \mathrm{min}$ on an HPLC system (LKB). After loading, the column was washed with $2.5 \mathrm{ml}$ buffer $\mathrm{A}$, and proteins were eluted with a linear 2 -hr salt gradient of $0-400 \mathrm{~mm}$ $\mathrm{NaCl}$ in buffer A, followed by a 10-min gradient of $400-1000$ $\mathrm{mM} \mathrm{NaCl}$ in buffer A. Fractions of $1.5 \mathrm{ml}$ were collected. The proteins eluting between 170 and $240 \mathrm{mM}$ (and containing both ATF/CREB and AP-1-binding activity; data not shown) were pooled and rechromatographed under the same conditions as described above.

\section{Preparation of cytoplasmic RNAs and RNase protection}

The preparation of cytoplasmic RNAs and RNase protection experiments were carried out as described elsewhere (Engel et al. 1988). The c-fos probe was kindly provided by M. Cole, and the junB probe was a generous gift of D. Nathans.

\section{DNA band-shift assays}

DNA band-shift assays were carried out essentially as described elsewhere (Hardy and Shenk 1988). The sequences of oligonucleotides used as probe or competitor DNAs in band-shift assays are listed in Table 1. All extracts were standardized for protein concentration before they were used. Binding reactions were carried out in a 10- $\mu$ l reaction volume, containing nuclear extracts $(0.2-2.0 \mu \mathrm{g}$ protein) or appropriate amounts of a column fraction, 10 fmoles of ${ }^{32} \mathrm{P}$-labeled $\left(5^{\prime} \mathrm{ends}\right)$ doublestranded oligonucleotide, and $1 \mu \mathrm{g}$ of poly[d(I-C)]. The final concentrations of buffers and salts were $10 \mathrm{mM}$ HEPES ( $\mathrm{pH} 7.9$ ) and $50-100 \mathrm{mM} \mathrm{NaCl}$. The binding reactions were incubated for 30-45 $\mathrm{min}$ at room temperature. DNA-protein complexes were separated from unbound DNA by electrophoresis in a $4 \%$ polyacrylamide gel [1.6 mm thick, $N, N^{\prime}$-methylene-bis-acrylamide/acrylamide :: $1: 20$ (wt/wt)] containing $10 \mathrm{mM}$ Tris- $\mathrm{HCl}$ $(\mathrm{pH} 8.0)$ and $1 \mathrm{mM}$ EDTA at $4^{\circ} \mathrm{C}$ with a voltage gradient of 15 $\mathrm{V} / \mathrm{cm}$. Where indicated, unlabeled double-stranded competitor DNA or protein A affinity-purified antibody was added to the binding reaction simultaneously with the $5^{\prime}$-end-labeled double-stranded oligonucleotide. For direct comparison of different competitor DNAs (Fig.3), films were preflashed and ex- posed for comparable times. All competitions were carried out in parallel and with the same preparation of ${ }^{32} \mathrm{P}$-labeled DNA.

Three antibodies were employed in band-shift experiments. Two were polyclonal rabbit antibodies prepared against synthetic peptides containing c-fos sequences /one was kindly provided by T. Curran; Curran et al. 1985; the second was obtained from Cambridge Research Biochemicals). The third was a rabbit polyclonal antibody prepared against a $\beta$-galactosidase fusion protein containing the carboxy-terminal 152 amino acids of the human c-jun polypeptide. The fusion protein contains the entire DNA-binding domain and the leucine zipper region of c-jun. The region contains a domain of $79 \%$ amino acid homology to junB and $88 \%$ to junD. Becuase of the homology between different iun proteins, the polyclonal serum reacts with different members of the jun gene family (M. Roberts, U. Müller, and T. Shenk; unpubl.).

\section{Acknowledgments}

We thank T. Curran for the fos antiserum, K. Ryder and D. Nathans for the junB plasmid DNA, and M. Cole for the c-fos plasmid DNA. We also thank members of our laboratory, especially Christopher Parks, for critical discussion during the work and reading of this manuscript. This work was supported by a grant from the National Cancer Institute (CA 38965). U.M. is a graduate student at the Universität $z u$ Köln and received fellowship support from the Fritz Thyssen Stiftung and the Deutsche Akademische Austausch Dienst while performing this work at Princeton University. M.P.R. is a postdoctoral fellow of the American Cancer Society (PF 3231), D.A.E. is a postdoctoral fellow of the National Cancer Institute (CA-08210), and T.S. is an American Cancer Society professor.

\section{References}

Angel, P., M. Imagawa, R. Chiu, B. Stein, R.J. Imbra, H.J. Rahmsdorf, C. Jonat, P. Herrlich, and M. Karin. 1987. Phorbol ester-inducible genes contain a common cis element recognized by a TPA-modulated trans-activator. Cell 49: 729-739.

Angel, P., K. Hattori, S. Tod, and M. Karin. 1988. The jun proto-oncogene is positively autoregulated by its product, jun/AP1. Cell 55: 875-885.

Berk, A.J. 1986. Adenovirus promoters and ElA transactivation. Annu. Rev. Genet. 20: 45-79.

Borrelli, E., R. Hen, and P. Chambon. 1984. Adenovirus-2 ElA products repress enhancer-induced stimulation of transcription. Nature 312: 608-612.

Bourne, H.R., P. Coffino, and G.M. Tomkins. 1975. Somatic genetic analysis of cyclic AMP action: Characterization of unresponsive mutants. J. Cell. Physiol. 85: 611-620.

Bradford, M.M. 1976. A rapid and sensitive method for the quantitation of microgram quantities of protein utilizing the principle of protein-dye binding. Anal. Biochem. 72: 248254.

Bravo, R., M. Neuberg, J. Burckhardt, J. Almendral, R. Wallich, and R. Muller. 1987. Involvement of common and cell type specific pathways in c-fos gene control: Stable induction by cAMP in macrophages. Cell 48: 251-260.

Chatterjee, P.K., M. Burner, S.J. Flint, and M.L. Harter. 1988. DNA-binding properties of an adenovirus 289R E1A protein. EMBO J. 7: 835-841.

Coffino, P., H.R. Bourne, and G.M. Tomkins. 1975. Somatic genetic analysis of cyclic AMP action: Selection of unresponsive mutants. J. Cell. Physiol. 85: 603-610. 
Cohen, D.R., P.C.P. Ferreira, R. Gentz, B.R. Franza, Jr., and T. Curran. 1989. The product of a fos-related gene, fra-1, binds cooperatively to the AP-1 site with Jun: Transcription factor $\mathrm{AP}-1$ is comprised of multiple protein complexes. Genes Dev. 3: 173-184.

Curran, T., C. Van Beveren, N. Ling, and I.M. Verma. 1985. Viral and cellular fos proteins are complexed with a 39,000 dalton cellular protein. Mol. Cell. Biol. 5: 167-172.

Curran, T., and B.R. Franza. 1988. Fos and jun: The AP-1 connection. Cell 55: 395-397.

Deutsch, P.J., J.P. Hoeffler, J.L. Jameson, and J.F. Habener. 1988. Cyclic AMP and phorbol ester-stimulated transcription mediated by similar DNA elements that bind distinct proteins. Proc. Natl. Acad. Sci. 85: 7922-7926.

Dignam, J.D., R.M. Lebovitz, and R.G. Roeder. 1983. Accurate transcription initiation by RNA polymerase II in a soluble extract from isolated mammalian nuclei. Nucleic Acids Res. 11: 1475-1489.

Distel, R.J., H.-S. Ro, B.S. Rosen, D.L. Groves, and B.M. Spiegelman. 1987. Nucleoprotein complexes that regulate gene expression in adipocyte differentiation: Direct participation of c-fos. Cell 49: 835-844.

Engel, D.A., S. Hardy, and T. Shenk. 1988. cAMP acts in synergy with E1A protein to activate transcription of the adenovirus early genes E4 and E1A. Genes Dev. 2: 1517-1528.

Ferguson, B., B. Krippl, O. Andrisani, N. Jones, H. Westphal, and M. Rosenberg. 1985. E1A 13 s and 12s mRNA products made in $\mathrm{E}$. coli both function as nucleus-localized transcription activators but do not directly bind DNA. Mol. Cell. Biol. 5: 2653-2661.

Franza, B.R., F.J. Rauscher, S.F. Josephs, and T. Curran. 1988. The fos-complex and fos-related antigens recognize sequence elements that contain AP-1 sites. Science 239: 1150-1153.

Fried, M., and D.M. Crothers. 1981. Equilibria and kinetics of lac repressor-operator interactions by polyacrylamide gel electrophoresis. Nucleic Acids Res. 9: 6505-6525.

Green, M.R., R. Treisman, and T. Maniatis. 1983. Transcriptional activation of cloned human $\beta$-globin genes by viral immediate-early gene products. Cell 35: 137-148.

Greenberg, M.E., L.A. Greene, and E.B. Ziff. 1985. Nerve growth factor and epidermal growth factor induce rapid transient changes in proto-oncogene transcription in $\mathrm{PCl} 12$ cells. J. Biol.Chem. 260: 14101-14110.

Hai, T., F. Liu, E.A. Allegretto, M. Karin, and M.R. Green. 1988. A family of immunologically related transcription factors that includes multiple forms of ATF and AP-1. Genes Dev. 2: 1216-1226.

Halbert, D.N., J.R. Cutt, and T. Shenk. 1985. Adenovirus early region 4 encodes functions required for efficient DNA replication, late gene expression, and host cell shutoff. I. Virol. 56: $250-257$.

Hanaka, S., T. Nishigaki, P.A. Sharp, and H. Handa. 1987.Regulation of in vitro and in vivo transcription of early-region IV of adenovirus type 5 by multiple cis-acting elements. Mol. Cell. Biol. 7: 2578-2587.

Hardy, S. and T. Shenk. 1988. Adenoviral control regions activated by E1A and the cAMP response element bind to the same factor. Proc. Natl. Acad. Sci. 85: 4171-4175.

Harlow, E., B. Franza, and C. Schley. 1985. Monoclonal antibodies specific for adenovirus early region 1A proteins: Extensive heterogeneity in early region 1 A products. J. Virol. 55: 533-546.

Hearing, P. and T. Shenk. 1985. Sequence-independent autoregulation of the adenovirus type 5 E1A transcription unit. Mol. Cell. Biol. 5: 3214-3221.
Hen, R., E. Borrelli, and P. Chambon. 1985. Repression of the immunoglobulin enhancer by the adenovirus E1A products. Science 230: 1391-1394.

Hidaka, H., M. Inagaki, S. Kawamoto, and Y. Sasaki. 1984. Isoquinoline sulfonamides, novel and potent inhibitors of cyclic nucleotide dependent protein kinase and protein kinase C. Biochemistry 23: 5036-5041.

Hurst, H. C. and N. Jones. 1987. Identification of factors that interact with the E1A-inducible adenovirus E3 promoter. Genes Dev. 1: 1132-1146.

Imagawa, M., R. Chiu, and M. Karin. 1987. Transcription factor AP-2 mediates induction by two different signal-transduction pathways: Protein kinase C and cAMP. Cell 51: 251260.

Jones, N. and T. Shenk. 1979. An adenovirus type 5 early gene function regulates expression of other early viral genes. Proc. Natl. Acad. Sci. 76: 3665-3669.

Jones, N.C., P.W.J. Rigby, and E.B. Ziff. 1988. Trans-acting protein factors and the regulation of eukayotic transcription: Lessons from studies on DNA tumor viruses. Genes Dev. 2: 267-281.

Kruijer, W., D. Schubert, and I.M. Verma. 1985. Induction of the proto-oncogene fos by nerve growth factor. Proc. Natl. Acad. Sci. 82: 7330-7334.

Lee, K.A.W., and M.R. Green. 1987. A cellular transcription factor E4F1 interacts with an ElA-inducible enhancer and mediates constitutive enhancer function in vitro. EMBO $\%$ 6: $1345-1353$.

Lee, K.A.W., T.-Y. Hai, L. SivaRaman, B. Thimmappaya, H.C. Hurst, N.C. Jones, and M.R. Green. 1987. A cellular protein, activating transcription factor, activates transcription of multiple E1A-inducible adenovirus early promoters. Proc. Natl. Acad. Sci. 84: 8355-8358.

Lee, W., P. Mitchell, and R. Tjian. 1987. Purified transcription factor AP-1 interacts with TPA-inducible enhancer elements. Cell 49: 741-752.

Leong, K., C. Brunet, and A.J. Berk. 1988. Factors responsible for the higher transcriptional activity of extracts of adenovirusinfected cells fractionate with the TATA box transcription factor. Mol. Cell. Biol. 8: 1765-1774.

Leza, M.A. and P. Hearing. 1988. Cellular transcription factor binds to adenovirus early region promoters and to a cyclic AMP response element. /. Virol. 62: 3003-3013.

- 1989. Independent cyclic AMP and E1A induction of adenovirus early region 4 expression. J. Virol. 63: 30573064.

Lillie, J.W., M. Green, and M.R. Green. 1986. An adenovirus E1A protein region required for transformation and transcriptional repression. Cell 46: 1043-1051.

Lillie, J.W., P.M. Loewenstein, M.R. Green, and M. Green. 1987. Functional domains of adenovirus type 5 E1A proteins. Cell 50: 1091-1100.

Lillie, J.W., and M.R. Green. 1989. Transcription activation by the adenovirus E1A protein. Nature 338: 39-44.

Lin, Y.-S. and M.R. Green. 1988. Interaction of a common cellular transcription factor, ATF, with regulatory elements in both E1A and cyclic AMP-inducible promoters. Proc. Natl. Acad. Sci. 85: 3396-3400.

Logan, J., S. Pilder, and T. Shenk. 1984. Functional analysis of adenovirus type 5 early region 1B. Cancer Cells 2: 527-532.

Montminy, M.R. and L.M. Bilezsikjian. 1987. Binding of a nuclear proteins to the cyclic AMP response element of the somatostatin gene. Nature 328: 175-178.

Nairn, A.C., H.C. Hemmings, Jr., and P. Greengard. 1985. Protein kinases in the brain. Annu. Rev. Biochem. 54: 931976. 
Nakabeppu, Y., K. Ryder, and D. Nathans. 1988. DNA binding activities of three murine jun proteins: Stimulation by fos. Cell 55: 907-915.

Nevins, J.R.. 1981. Mechanism of activation of early viral transcription by the adenovirus E1A gene product. Cell 26: 213 220.

Piette, J., S.I. Hirai, and M. Yaniv. 1988. Constitutive synthesis of activator protein 1 transcription factor after viral transformation of mouse fibroblasts. Proc. Natl. Acad. Sci. 85: $3401-3405$.

Pertovaara, L., L. Sistonen, T. Bos, P.K. Vogt, J. Keski-Oja, and K. Alitalo. 1989. Enhanced jun gene expression is an early genomic response to transforming growth factor $\beta$ stimulation. Mol. Cell. Biol. 9: 1255-1262.

Rauscher III, F.J., P.J. Voulalas, B.R. Franza, Jr., and T. Curran. 1988a. Fos and Jun bind cooperatively to the AP-1 site: Reconstitution in vitro. Genes Dev. 2: 1687-1699.

Rauscher, F.J., L.C. Sambucetti, T. Curran, R.J. Distel, and B.M. Spiegelman. 1988b. Common DNA binding site for fos protein complexes and transcription factor AP-1. Cell 52: 471480.

Rice, S. and D.F. Klessig. 1985. Isolation and analysis of adenovirus type 5 mutants containing deletions in the gene encoding the DNA-binding protein. I. Virol. 56: 767-778.

Roesler, W.J., G.R. Vandenbark, and R.W. Hanson. 1988. Cyclic $\mathrm{AMP}$ and the induction of eukaryotic gene transcription. $I$. Biol. Chem. 263: 9063-9066.

Ryder, K., L.F. Lau, and D. Nathans. 1988. A gene activated by growth factors is related to the oncogene v-jun. Proc. Natl. Acad. Sci. 85: 1487-1491.

Sassone-Corsi, P. 1988. Cyclic AMP induction of early adenovirus promoters involves sequences required for ElA transactivation. Proc. Natl. Acad. Sci. 85: 7192-7196.

Schneider, J.F., F. Fisher, C.R. Goding, and N.C. Jones. 1987. Mutational analysis of the adenovirus ElA gene: The role of transcriptional regulation in transformation. EMBO $I$. 6: $2053-2060$.

Shenk, T., N. Jones, W. Colby, and D. Fowlkes. 1980. Functional analysis of adenovirus 5 host range deletion mutants defective for transformation of rat embryo cells. Cold Spring Harbor Symp. Quant. Biol. 44: 367-375.

Simon, M.C., R.M. Fisch, B.J. Benecke, J.R. Nevins, and N. Heintz. 1988. Definition of multiple, functionally distinct TATA elements, one of which is a target in the hsp70 promoter for E1A regulation. Cell 52: 723-729.

SivaRaman, L., S. Subramanian, and B. Thimmappaya. 1986. Identification of a factor in HeLa cells specific for an upstream transcriptional control sequence of an ElA-inducible adenovirus promoter and its relative abundance in infected and uninfected cells. Proc. Natl. Acad. Sci. 83: 5914-5918.

SivaRaman, L. and B. Thimmappaya. 1987. Two promoter-specific host factors interact with adjacent sequences in an ElA-inducible adenovirus promoter. Proc. Natl. Acad. Sci. 84: 6112-6116.

Spindler, K.R., D.S.E. Rosser, and A.J. Berk. 1984. Analysis of adenovirus transforming proteins from early region $1 \mathrm{~A}$ and $1 \mathrm{~B}$ with antisera to inducible fusion antigens produced in Escherichia coli. J. Virol. 49: 132-141.

Stein, R.W. and E.B. Ziff. 1987. Repression of insulin gene expression by adenovirus type 5 E1A proteins. Mol. Cell. Biol. 7: 1164-1170.

Thimmappaya, B., C. Weinberger, R.J. Schneider, and T. Shenk. 1982. Adenovirus VAI RNA required for efficient translation of viral mRNAs at late times after infection. Cell 31: 543551.

Velcich, A. and E.B. Ziff. 1985. Adenovirus ElA proteins repress transcription from the SV40 early promoter. Cell 40: 705716.

Wu, L., D.S.E. Rosser, M.C. Schmidt, and A.J. Berk. 1987. A TATA box implicated in ElA transcriptional activation of a simple adenovirus 2 promoter. Nature 326: $512-515$.

Yee, S., D.T. Rowe, M.L. Tremblay, M. McDermott, and P.E. Branton. 1983. Identification of human adenovirus early region 1 products by using antisera against synthetic peptides corresponding to the predicted carboxy termini. J. Virol. 46: 1003-1013.

Zajchowski, D.A., P. Jalinot, and C. Kedinger. 1988. E1A-mediated stimulation of the adenovirus EIII promoter involves an enhancer element within the nearby EIIA promoter. $J$. Virol. 62: 1762-1767. 


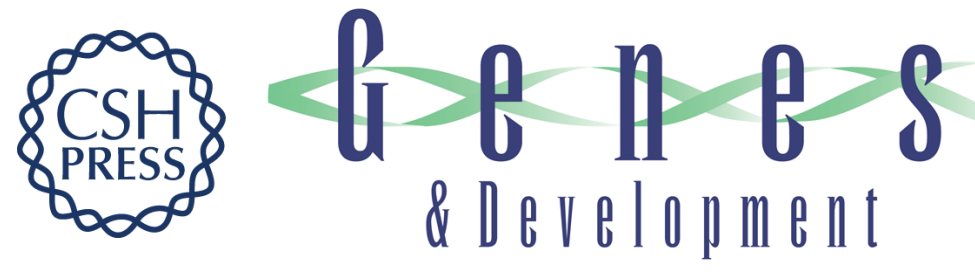

\section{Induction of transcription factor AP-1 by adenovirus E1A protein and cAMP.}

U Müller, M P Roberts, D A Engel, et al.

Genes Dev. 1989, 3:

Access the most recent version at doi:10.1101/gad.3.12a.1991

References This article cites 69 articles, 37 of which can be accessed free at:

http://genesdev.cshlp.org/content/3/12a/1991.full.html\#ref-list-1

License

Email Alerting

Service

Receive free email alerts when new articles cite this article - sign up in the box at the top right corner of the article or click here.

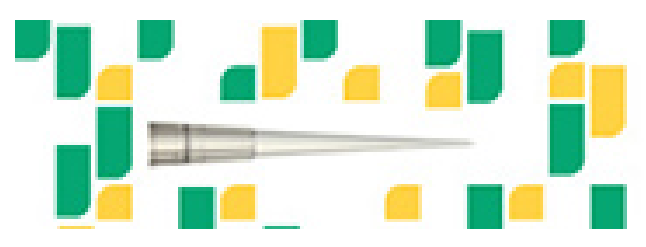

Focused on your science. 